\title{
EFFECT OF PLANTING METHOD AND SPRAYING WITH THE ORGANIC NUTRITION SOLUTION ON GROWTH AND YIELD OF TWO RADISH VARIETIES (RAPHANUS SATIVUS L.)
}

Abdullah M. S. AL-Dabbagh

Dept. of Hort. \& Landscape Design Collage of Agric. \&Forestry

Mosul university - Iraq.

E-mail:abdullah.aldabbagh@uomosul.edu.iq

\begin{abstract}
This study was conducted in vegetable field of Horticulture Department /college of Agric. and forestry / Mosul University during the winter season of 20172018 , to study the effect of two methods of planting (plots and furrows), and spraying with different concentration levels: 0,3 , and $6 \mathrm{ml}^{-1} \mathrm{I}^{-1}$ of nutritious organic solution, Tecamin Max, on the growth and production of two varieties of radish, red Celesta, and black Rudi.The results have showed a significant of furrows method as compared to the plot method when it comes to the majority of the studied characteristic, including: leaves area, the length and diameter of the root, the dry weight of the roots, the weight of the single plant, and the total yield. As for spraying with the nutritious organic solution, Tecamin Max, with $3 \mathrm{ml}^{-1^{-1}}$ concentration levels, it showed a significant advantage regarding comparison in the length and diameter of root. The black varieties was advantageous when it came to dry root weight, while the red was advantageous in the weight of the single plant, the total yield, and the root length. Dual and triple interaction have also matched single interaction of each factor, with the triple interaction of furrow planting, while spraying with $3 \mathrm{ml}^{-1^{-1}}$ of Tecamin Max for the red varieties providing the highest ratio of the single plant of $171.6 \mathrm{~g}$, and the highest total of roots of $22.88 \mathrm{t}^{\mathrm{h}} \mathrm{ha}^{-1}$.

Key words: Radish, Planting method, Tecamin max, Yield.
\end{abstract}

Received:26/2/2019 Accepted:30/6/2019

\section{INTRODUCTION}

Radish (Raphanus sativus L) belongs to the Brassicaceae family. It is one of the stored root winter plants which are common in Iraq, and is farmed for the leafs and roots which are eaten fresh, with the roots of some of its' varieties cooked (Hasan, 2003). The high nutritious value of radish isn't just for the fact that it possess plenty of nutritious factors alone, but due to its' medicinal benefits as well, since medical reports have shown that radish is amongst vegetables that help in lowering cholesterol percentages and blood sugar, in addition to providing protection from cancer (Boras, 1993), as well as being of benefit in curing headaches, liver diseases, gallbladder, and getting rid of urine stones (Sadhu, 1993). Using amino-acids is one of the modern techniques which provide good agricultural produce (Cerdana et al. 2009), due to its' positive effects on plenty of physiological and biological operations within the plant, since plants do need to continue growing and producing (Hounsome et al. 2008). It helps plants in responding to physiological circumstances of the environment due to its' role in stimulating the work and production on many organic compounds (Ibrahim et al. 2010). Al- 
Hamdani et al. (2017) have found that spraying Tecamin solution on potato plants with 2 and $4 \mathrm{ml} .1^{-1}$ has resulted in significant increase in plant length, total of chlorophyll in leaves, and the leaf area of the leaf in comparison. Radish varieties differ from each other in the shape of root (length and diameter), weight, size, color, and period of growth. Most local varieties are of low quality and delayed in production, while foreign imported ones are good when it comes to quality and quantity of produce, in addition to early productions, as mentioned in (Cools, 1981; Norbut, 1985). We didn't have any resources regarding the use of amino-acid Tecamin Max on radish, while some resources mentioned the use of some organic sources on that crop, as when AbdulRahman (2014) mentioned in his study of the spraying of seaweed extracts Alga600 and its' effect in the growth and productivity of two varietiess of local and foreign radish, and how spraying with the two used concentrations of 4 and $6 \mathrm{ml} .1^{-1}$ had the increased in most studied characteristic in comparison with the local varieties having the increased in the studied characteristic compared to the foreign varieties. Hammad (2015) in his study on two varities of radish (local red and foreign red) with the use of Humix (ANT) spraying solution, illustrated that spraying with the used concentrations of 2 and $4 \mathrm{~cm}^{3} \cdot 1^{-1}$ showed an increased in local varieties within most studied characteristic compared with the foreign one. Crop planting methods are defined as the procedures in which seeds are placed so to be accommodated towards the ideal circumstances for growing, and for the produce to continue growing well (Abdel-Gawad et al. 1989). Generally, there are three methods to planting seeds in the field, plots, furrows, and raised beds, each method having its' own positives and negatives which might differ from one region to another, and from one farmer to another, yet we have no study regarding the effect of planting methods to radish produce, but we can conclude from our observation in the field that the method followed in growing it in northern Iraq is by plots. Due to the rising demand on radish, and lack of studies regarding determining the level of crop response to planting method and amino-acid fertilizing on two of the imported varieties of radish, this study came to shed light on the following: 1- Improve the vegetative growing characteristic and the produce of radish with spraying amino-acids on leaves (Tecamin Max).

2- Find the best method to farm radish (plots or furrows), and study the effect of those factors on two varieties of imported radish that are to be used locally in the future.

\section{MATERIAL AND METHODS}

The experiment was conducted at the vegetables field, belonging to the Department of Horticulture and Landscape Design, College of Agriculture and Forestry, University of Mosul, during the agricultural season of 2017-2018, to study the effect of planting methods (plots and furrows) and spraying the organic solution Tecamin Max on growth and yield of two varieties of imported radish. The experiment land was plowed, softened, and divided into furrows and plots, with each experiment unit for each method being $1.5 \mathrm{~m}^{2}$, with 20 plants per each experiment unit, and $15 \mathrm{~cm}$ between plants. The furrow experiment unit consisted of two furrows in $1 \mathrm{~m}$ length and $65 \mathrm{~cm}$ width, and 10 plants per furrow on both sides. The plot experiment unit consisted of 4 line $1 \mathrm{M}$ length lines, with $30 \mathrm{~cm}$ between 
the lines, and 5 plants per line. The seeds for both varieties used were planted on the $5^{\text {th }}$ October 2017.Random soil samples were taken from the field befor to planting, with different depths to determine chemical and physical characteristic of the soil which was performed at the central laboratory College of Agriculture and Forestry University of Mosul (Table 1).

Table (1): Some chemical and physical characteristic of the field soil

\begin{tabular}{|c|c|c|c|c|c|c|c|c|}
\hline Weave & \multicolumn{3}{|l|}{ Separated Material $\left(\mathrm{gm} / \mathrm{K}^{-1}\right)$} & $\mathrm{K}$ & $\mathrm{P}$ & $\mathrm{N}$ & $\mathrm{EC}$ & $\mathrm{pH}$ \\
\hline $\begin{array}{c}\text { Clay } \\
\text { Soil }\end{array}$ & Sand & Slit & Clay & $\mathrm{ppm}$ & $\mathrm{ppm}$ & $\mathrm{ppm}$ & $\mathrm{ds}^{-1}$ & ----- \\
\cline { 2 - 9 } & 455.5 & 105 & 439.5 & 5 & 1.5 & 59 & 0.27 & 7.5 \\
\hline
\end{tabular}

The expeiment included three factors: The first: planting method: Which includes a- planting in furrows.b- planting in plots. The second: Spraying with the nurturing solution Tacamin Max, whose ingredients are illustrated in Table (2), with three levels: Zero (control), $3 \mathrm{ml}^{-1^{-1}}, 6 \mathrm{ml} .1^{-1}$. The third factor: Two varieties of radish (Red Celesta and Black Rudi) producer, the Turkish company Argeto. Leaves were sprayed with the nutritious Tecamin Max solution three times, the first: 1 month after planting, on the $5^{\text {th }}$ of November 2017, and repated the spraying with 15 days between the brush and other.

Table (2): compounds of fertilizer used in experiment(Tecamin Max)

\begin{tabular}{|c|l|c|c|}
\hline \multicolumn{3}{|c|}{ Tecamin Max } \\
\hline N\% & $\begin{array}{l}\text { Varieties of amino acids in Tecamin } \\
\max \end{array}$ & $\begin{array}{l}\text { Total A. } \\
\text { acid \% }\end{array}$ & Varieties of extract \\
\hline 9.5 & $\begin{array}{l}\text { Isoleocine, Leucine, Methionine, } \\
\text { Fenilalanine, Tryotofan, Tirosino, } \\
\text { Valine, Cisteine, Glicine, Proline, } \\
\text { Arginine, Histidine, Ac. Glutamic, } \\
\text { Ac. Aspartic, Asparagine, Glutamine, } \\
\text { Serine, Threonine, Alanine, Lysine. }\end{array}$ & 18.4 & $\begin{array}{c}\text { Free amino acid from } \\
\text { plant source by } \\
\text { Spanish company }\end{array}$ \\
\hline
\end{tabular}

The experiment was conducted in the field using factorial experiment within split plots, all within the design of randomized complete block design (RCBD) and with three repleciat where the main plot inclouding planting method fertilizer factors and varieties in sub plot. The comparison was made between mediums according to the least significant difference at the possibility rate of 5\% (Al-Rawi and Abdul Aziz, 2000). To evaluate radish plant growth and yield, the following characteristic were estimated: The height of the plant $(\mathrm{cm})$, number of leaves, leaf area $(\mathrm{cm})^{2}$, dry matter percentage for leaves, chlorophyll percentage in leaves, roots length $(\mathrm{cm})$, root diameter $(\mathrm{cm})$, string length of the roots, dry roots $(\%)$, single plant weight, total yield of roots t.ha ${ }^{-1}$.

\section{RESULTS}

1- The effect of planting method and spraying with nutritious organic solution Tecamin Max in the vegetative growth charactrestic of two varities of radish: 


\subsection{Plant height (cm)}

Table (3) results show no significant differences between both planting methods, plots and furrows, and in concentration percentages of Tecamin Max used on the plant height on. As for the effect of dual ineraction of studied factors, the interaction between furrow planting method and low concentration Tecamin Max, the interaction between furrow planting method and the red radish varieties and the interaction between the red radish varieties and low concentration Tecamin Max resulted in the highest values recorded of $(30.16,28.74$, and $27.97 \mathrm{~cm})$ consecutively. The triple interaction effect on the other hand provided furrow plants of the red varieties, which were sprayed with low concentration Tecamin Max with the highest recorded value regarding plant height of $30.5 \mathrm{~cm}$, while the comparison value of the plot planting method for the red varieties was the least of the values at $20.10 \mathrm{~cm}$.

Table (3): Effect of planting method and spraying with Tecamin Max of two varieties of radish on Plant height $(\mathrm{cm})$.

\begin{tabular}{|c|c|c|c|c|c|c|}
\hline \multirow[t]{2}{*}{ Varieties } & \multirow{2}{*}{$\begin{array}{l}\text { Planting } \\
\text { method }\end{array}$} & \multicolumn{3}{|c|}{ Tecamin Max ml.1 ${ }^{-1}$} & \multirow{2}{*}{$\begin{array}{l}\text { Variety X } \\
\text { Planting } \\
\text { method }\end{array}$} & \multirow{2}{*}{$\begin{array}{l}\text { Average } \\
\text { of Planting } \\
\text { method }\end{array}$} \\
\hline & & 0 & 3 & 6 & & \\
\hline \multirow{2}{*}{$\begin{array}{l}\text { Red } \\
\text { "Celesta" }\end{array}$} & Plot & $20.10 \mathrm{e}$ & $25.44 \mathrm{bcd}$ & $24.68 \mathrm{~cd}$ & $23.4 \mathrm{~b}$ & $24.07 \mathrm{a}$ \\
\hline & Furrow & $28.70 \mathrm{abc}$ & $30.5 \mathrm{a}$ & $27.02 \mathrm{a}-\mathrm{d}$ & $28.74 a$ & $28.66 \mathrm{a}$ \\
\hline \multirow{2}{*}{$\begin{array}{l}\text { Black } \\
\text { "Rudi" }\end{array}$} & Plot & $24.81 \mathrm{~cd}$ & 23.94de & $25.5 \mathrm{bcd}$ & $24.75 b$ & \\
\hline & Furrow & 28.31a-d & $29.83 \mathrm{ab}$ & $27.64 a-d$ & $28.59 \mathrm{a}$ & \\
\hline \multirow{2}{*}{$\begin{array}{l}\text { Planting method } \\
\text { X Tecamin Max }\end{array}$} & Plot & $22.45 \mathrm{c}$ & $24.69 \mathrm{bc}$ & $25.09 \mathrm{bc}$ & \multirow{2}{*}{$\begin{array}{l}\text { Average } \\
\text { of Variety }\end{array}$} & \\
\hline & Furrow & $28.5 \mathrm{a}$ & $30.16 a$ & $27.33 \mathrm{ab}$ & & \\
\hline \multirow{2}{*}{$\begin{array}{l}\text { Variety X } \\
\text { Tecamin Max }\end{array}$} & Red & $24.40 \mathrm{~b}$ & $27.97 \mathrm{a}$ & $25.85 \mathrm{ab}$ & $26.07 \mathrm{a}$ & \\
\hline & Black & $26.56 \mathrm{ab}$ & $26.88 \mathrm{ab}$ & $26.21 \mathrm{a}$ & $26.67 \mathrm{a}$ & \\
\hline \multicolumn{2}{|c|}{ Average of Tecamin Max } & $25.48 \mathrm{a}$ & $27.42 \mathrm{a}$ & $26.21 \mathrm{a}$ & & \\
\hline
\end{tabular}

Average in each column for single and interaction between factores have the same letters are not significant acording to duncan multiple test at $0.05 \%$

\subsection{Number of leaves.plant ${ }^{-1}$}

Results of table (4) show a significant differances of furrow plants over plot plants in leaves number characteristic with an increase rate reaching $10.02 \%$, while spraying nutritious Tecamin Max solution and varities of plant did not have any significant affect regarding this character. While resulted in highest values of 13.23 leaf.plant ${ }^{-1}$ for furrow planting and high concentration of Tecamin Max, 13.33 leaf.plant ${ }^{-1}$ for furrow planting and read varieties of radish, and 13.10 leaf.plant $^{-1}$ for red varieties of radish and low concentration Tecamin. Triple interaction between furrow planting, high concentration Tecamin of $6 \mathrm{ml}^{-1} \mathrm{l}^{-1}$, and black varieties of 
radish, which resulted in the highest value for this characteristic of 14.00 leaf.plant $^{-}$ ${ }^{1}$, and had only a significant advantage over plot plants of the black varieties which were not treated with Tecamin Max, resulting in its' highest value at 9.93 leaf.plant ${ }^{-1}$.

Table (4): Effect of planting method and spraying with Tecamin Max of two varieties of radish on leaves number $\left(\right.$ plant $\left.^{-1}\right)$.

\begin{tabular}{|c|c|c|c|c|c|c|}
\hline \multirow[t]{2}{*}{ Varieties } & \multirow{2}{*}{$\begin{array}{l}\text { Planting } \\
\text { method }\end{array}$} & \multicolumn{3}{|c|}{ Tecamin Max ml. ${ }^{-1}$} & \multirow{2}{*}{$\begin{array}{l}\text { Variety X } \\
\text { Planting } \\
\text { method }\end{array}$} & \multirow{2}{*}{$\begin{array}{c}\text { Average of } \\
\text { Planting method }\end{array}$} \\
\hline & & 0 & 3 & 6 & & \\
\hline \multirow{2}{*}{$\begin{array}{l}\text { Red } \\
\text { "Celesta" }\end{array}$} & Plot & $11.90 \mathrm{ab}$ & $12.10 \mathrm{ab}$ & $12.00 \mathrm{ab}$ & $11.51 \mathrm{~b}$ & $11.76 \mathrm{~b}$ \\
\hline & Furrow & $12.90 \mathrm{a}$ & $13.07 \mathrm{a}$ & $12.47 \mathrm{a}$ & $13.33 \mathrm{a}$ & $13.07 \mathrm{a}$ \\
\hline \multirow{2}{*}{$\begin{array}{l}\text { Black } \\
\text { "Rudi" }\end{array}$} & Plot & $9.93 \mathrm{~b}$ & $13.13 \mathrm{a}$ & $11.47 \mathrm{ab}$ & $12.00 \mathrm{ab}$ & \\
\hline & Furrow & $12.93 \mathrm{a}$ & $13.07 \mathrm{a}$ & $14.00 \mathrm{a}$ & $12.81 \mathrm{ab}$ & \\
\hline \multirow{2}{*}{$\begin{array}{l}\text { Planting method } \\
\text { X Tecamin Max }\end{array}$} & Plot & $10.92 \mathrm{~b}$ & $12.62 \mathrm{a}$ & $11.73 \mathrm{ab}$ & \multirow{2}{*}{$\begin{array}{c}\text { Average of } \\
\text { Variety }\end{array}$} & \\
\hline & Furrow & $12.92 \mathrm{a}$ & $13.07 \mathrm{a}$ & $13.23 \mathrm{a}$ & & \\
\hline \multirow{2}{*}{$\begin{array}{l}\text { Variety X } \\
\text { Tecamin Max }\end{array}$} & Red & $11.43 \mathrm{a}$ & $13.10 \mathrm{a}$ & $12.73 \mathrm{a}$ & $12.42 \mathrm{a}$ & \\
\hline & Black & $12.40 \mathrm{a}$ & $12.58 \mathrm{a}$ & $12.23 \mathrm{a}$ & $12.41 \mathrm{a}$ & \\
\hline \multicolumn{2}{|c|}{ Average of Tecamin Max } & $11.92 \mathrm{a}$ & $12.84 \mathrm{a}$ & $12.48 \mathrm{a}$ & & \\
\hline
\end{tabular}

Average in each column for single and interaction between factores have the same letters are not significant acording to duncan multiple test at $0.05 \%$

\section{3 leaf area $\left(\mathrm{cm}^{2}\right.$.plant $\left.{ }^{-1}\right)$}

Table (5) shows a significant advantage of furrow planting over plot planting when it comes to plant leaf area with an increase of $10.02 \%$, while Tecamin Max spraying and varieties of radish had no significant affect on this characteristic. Dual interaction of studied factors were in having furrow planting with low concentration Tecamin Max, Furrow planting with red varieties of radish, and black varieties of radish with low concentration Tecamin Max, resulting in the highest values of $\left(1730.1,1591.3\right.$, and $\left.1505.1 \mathrm{~cm}^{2}\right)$ consecutively. Triple interaction of furrow planting with low concentration of Tecamin Max of $3 \mathrm{ml}^{-1^{-1}}$ and the black varieties of radish have resulted in the highest value of $1778.1 \mathrm{~cm}^{2}$, and had a significant advantage over plot plants of the red varieties of radish that were untreated with the nutritious Tecamin Max solution which registered its' lowest value at $650 \mathrm{~cm}^{2}$. 
Mesopotamia J. of Agric.

Vol. (47) No. (2) 2019
ISSN: 2224 - 9796 (Online)

ISSN: 1815 - $316 \mathrm{X}$ (Print)

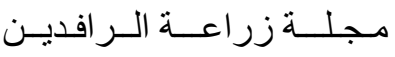

المجلد (47) العدد (2) 2019

Table (5): Effect of planting method and spraying with Tecamin Max of two varieties of radish on leaves area $\left(\mathrm{cm}^{2}\right)$.

\begin{tabular}{|c|c|c|c|c|c|c|}
\hline \multirow[t]{2}{*}{ Varieties } & \multirow{2}{*}{$\begin{array}{l}\text { Planting } \\
\text { method }\end{array}$} & \multicolumn{3}{|c|}{ Tecamin Max ml. ${ }^{-1}$} & \multirow{2}{*}{$\begin{array}{l}\text { Variety X } \\
\text { Planting } \\
\text { method }\end{array}$} & \multirow{2}{*}{$\begin{array}{c}\text { Average of } \\
\text { Planting method }\end{array}$} \\
\hline & & 0 & 3 & 6 & & \\
\hline \multirow{2}{*}{$\begin{array}{l}\text { Red } \\
\text { "Celesta" }\end{array}$} & Plot & $650.0 \mathrm{~d}$ & 1018.4 & $1081.5 \mathrm{~cd}$ & $908.32 \mathrm{c}$ & $1064.95 b$ \\
\hline & Furrow & $1731.2 \mathrm{ab}$ & $1682.1 \mathrm{ab}$ & $1360.5 \mathrm{abc}$ & $1591.3 \mathrm{a}$ & $1551.55 \mathrm{a}$ \\
\hline \multirow{2}{*}{$\begin{array}{l}\text { Black } \\
\text { "Rudi" }\end{array}$} & Plot & $1156.5 \mathrm{c}$ & $1232.1 b c$ & 1276.2abc & $1221.6 \mathrm{~b}$ & \\
\hline & Furrow & 1497.4abc & $1778.1 \mathrm{a}$ & $1260.0 \mathrm{bc}$ & $1511.8 \mathrm{a}$ & \\
\hline \multirow{2}{*}{$\begin{array}{l}\text { Planting method } \\
\text { X Tecamin Max }\end{array}$} & Plot & $890.7 d$ & $1125.2 \mathrm{~cd}$ & $1178.9 \mathrm{~cd}$ & \multirow{2}{*}{$\begin{array}{c}\text { Average of } \\
\text { Variety }\end{array}$} & \\
\hline & Furrow & $1614.3 \mathrm{ab}$ & $1730.1 \mathrm{a}$ & $1310.2 b c$ & & \\
\hline \multirow{2}{*}{$\begin{array}{l}\text { Variety X } \\
\text { Tecamin Max }\end{array}$} & Red & $1178.1 \mathrm{a}$ & $1350.3 \mathrm{a}$ & $1221.0 \mathrm{a}$ & $1249.7 \mathrm{a}$ & \\
\hline & Black & $1326.9 \mathrm{a}$ & $1505.1 \mathrm{a}$ & $1268.1 \mathrm{a}$ & $1366.7 \mathrm{a}$ & \\
\hline \multicolumn{2}{|c|}{ Average of Tecamin Max } & $1252.5 \mathrm{a}$ & $1427.7 \mathrm{a}$ & $1244.5 \mathrm{a}$ & & \\
\hline
\end{tabular}

Average in each column for single and interaction between factores have the same letters are not significant acording to duncan multiple test at $0.05 \%$

\subsection{Percentage of dry leaves.}

Table (6) results show having no significant effect of the three studied factors and their dual and triple interaction over the percentage of dry leaf.

Table (6): Effect of planting method and spraying with Tecamin Max of two varieties of radish on percentage of dry leaf $(\%)$.

\begin{tabular}{|c|c|c|c|c|c|c|}
\hline \multirow[t]{2}{*}{ Varieties } & \multirow{2}{*}{$\begin{array}{l}\text { Planting } \\
\text { method }\end{array}$} & \multicolumn{3}{|c|}{ Tecamin Max ml. ${ }^{-1}$} & \multirow{2}{*}{$\begin{array}{l}\text { Variety X } \\
\text { Planting } \\
\text { method }\end{array}$} & \multirow{2}{*}{$\begin{array}{c}\text { Average of } \\
\text { Planting method }\end{array}$} \\
\hline & & 0 & 3 & 6 & & \\
\hline \multirow{2}{*}{$\begin{array}{l}\text { Red } \\
\text { "Celesta" }\end{array}$} & Plot & $12.86 \mathrm{a}$ & $12.06 \mathrm{a}$ & $12.86 \mathrm{a}$ & $12.59 \mathrm{a}$ & $12.73 \mathrm{a}$ \\
\hline & Furrow & $12.27 \mathrm{a}$ & $12.13 \mathrm{a}$ & $11.68 \mathrm{a}$ & $12.02 \mathrm{a}$ & $12.26 \mathrm{a}$ \\
\hline \multirow{2}{*}{$\begin{array}{l}\text { Black } \\
\text { "Rudi" }\end{array}$} & Plot & $13.25 \mathrm{a}$ & $12.63 \mathrm{a}$ & $12.71 \mathrm{a}$ & $12.86 \mathrm{a}$ & \\
\hline & Furrow & $11.98 \mathrm{a}$ & $13.20 \mathrm{a}$ & $12.29 \mathrm{a}$ & $12.49 \mathrm{a}$ & \\
\hline \multirow{2}{*}{$\begin{array}{l}\text { Planting method } \\
\text { X Tecamin Max }\end{array}$} & Plot & $13.06 \mathrm{a}$ & $12.34 \mathrm{a}$ & $12.79 \mathrm{a}$ & \multirow{2}{*}{$\begin{array}{c}\text { Average of } \\
\text { Variety }\end{array}$} & \\
\hline & Furrow & $12.12 \mathrm{a}$ & $12.67 \mathrm{a}$ & $11.98 \mathrm{a}$ & & \\
\hline \multirow{2}{*}{$\begin{array}{l}\text { Variety X } \\
\text { Tecamin Max } \\
\end{array}$} & Red & $12.56 \mathrm{a}$ & $12.09 \mathrm{a}$ & $12.27 \mathrm{a}$ & $12.31 \mathrm{a}$ & \\
\hline & Black & $12.61 \mathrm{a}$ & $12.91 \mathrm{a}$ & $12.50 \mathrm{a}$ & $12.68 \mathrm{a}$ & \\
\hline \multicolumn{2}{|c|}{ Average of Tecamin Max } & $12.59 \mathrm{a}$ & $12.5 \mathrm{a}$ & $12.38 \mathrm{a}$ & & \\
\hline
\end{tabular}

Average in each column for single and interaction between factores have the same letters are not significant acording to duncan multiple test at $0.05 \%$ 


\subsection{Total chlorophyll percentage in leaves (SPAD).}

Table (7) results show non significant effect of the three studied factors on chlorophyll percentage in leaves. As for dual interaction of studied factors, plot planting with low concentration Texamin Max spray, furrow planting with the black varieties of radish, and the black varieties of radish with high concentration of Tecamin Max, all resulted in the highest recorded values of (55.02, 54.45, and 54.61 SPAD) consecutively. While triple interaction of furrow with black Rudi of radish planting spraying with high concentration of Tecamin Max have resulted in the highest recorded values of 56.36 SPAD, which all had a significant difference in comparison to plot plants of the red celesta and untreated with Tecamin Max, which resulted in its' lowest values at 48.73 SPAD.

Table (7): Effect of planting method and spraying with Tecamin Max of two varieties of radish on chlorophyll (SPAD).

\begin{tabular}{|c|c|c|c|c|c|c|}
\hline \multirow[t]{2}{*}{ Varieties } & \multirow{2}{*}{$\begin{array}{l}\text { Planting } \\
\text { method }\end{array}$} & \multicolumn{3}{|c|}{ Tecamin Max ml. ${ }^{-1}$} & \multirow{2}{*}{$\begin{array}{l}\text { Variety X } \\
\text { Planting } \\
\text { method }\end{array}$} & \multirow{2}{*}{$\begin{array}{c}\text { Average of } \\
\text { Planting method }\end{array}$} \\
\hline & & 0 & 3 & 6 & & \\
\hline \multirow{2}{*}{$\begin{array}{l}\text { Red } \\
\text { "Celesta" }\end{array}$} & Plot & $48.73 \mathrm{c}$ & $51.56 \mathrm{abc}$ & $52.10 \mathrm{abc}$ & $50.80 \mathrm{~b}$ & $51.48 \mathrm{a}$ \\
\hline & Furrow & $53.25 \mathrm{abc}$ & $55.70 \mathrm{a}$ & $52.53 \mathrm{abc}$ & $53.82 \mathrm{a}$ & $54.14 \mathrm{a}$ \\
\hline \multirow{2}{*}{$\begin{array}{l}\text { Black } \\
\text { "Rudi" }\end{array}$} & Plot & $53.15 \mathrm{abc}$ & $50.46 \mathrm{bc}$ & $52.86 \mathrm{abc}$ & $52.16 \mathrm{ab}$ & \\
\hline & Furrow & $52.65 \mathrm{abc}$ & $45.35 \mathrm{ab}$ & $56.36 \mathrm{a}$ & $54.45 \mathrm{a}$ & \\
\hline \multirow{2}{*}{$\begin{array}{l}\text { Planting method } \\
\text { X Tecamin Max }\end{array}$} & Plot & $52.95 \mathrm{ab}$ & $55.02 \mathrm{a}$ & $54.45 \mathrm{a}$ & \multirow{2}{*}{$\begin{array}{c}\text { Average of } \\
\text { Variety }\end{array}$} & \\
\hline & Furrow & $50.94 \mathrm{~b}$ & $51.01 \mathrm{~b}$ & $52.48 \mathrm{ab}$ & & \\
\hline \multirow{2}{*}{$\begin{array}{l}\text { Variety X } \\
\text { Tecamin Max }\end{array}$} & Red & $50.99 \mathrm{~b}$ & $53.63 \mathrm{ab}$ & $52.31 \mathrm{ab}$ & $52.31 \mathrm{a}$ & \\
\hline & Black & $52.90 \mathrm{ab}$ & $52.40 \mathrm{ab}$ & $54.61 \mathrm{a}$ & $53.30 \mathrm{a}$ & \\
\hline \multicolumn{2}{|c|}{ Average of Tecamin Max } & $51.94 \mathrm{a}$ & $53 a$ & $53.46 \mathrm{a}$ & & \\
\hline
\end{tabular}

Average in each column for single and interaction between factores have the same letters are not significant acording to duncan multiple test at $0.05 \%$

2- The effect of planting method and spraying the Tecamin Max on the roots growth of two varieties of radish.

\subsection{Length and diameter of the root $(\mathbf{c m})$}

Results of Tables (8 and 9) show a significant advantage of furrow planting over plot planting gave heighest values of length and diameter of the root, with an increase of 15.9 and 23.6\%, while treating with low concentration Tecamin Max of $3 \mathrm{ml} .1^{-1}$ have resulted in the highest values of both characteristic, and had no significant difference compared with high concentration spraying of $6 \mathrm{mll}^{1-1}$ with an increase rate of 7.58 and $6.20 \%$ for both characteristic consecutively. As for the varieties effect, the red radish varities had the superior the black radish varities in 
both characteristic with a significant increase of $14.70 \%$ in root length, while either varieties didn't show a significant increase regarding rood diameter Dual interaction between radish varities and planting method regarding both characteristic had a similar affect on both characteristic as the one of the individual interaction with furrow plants of the red radish varities having the highest values and not being significantly different from furrow plants of the black varieties when it comes to rood diameter only. Dual interaction of furrow plants with low concentration of nutritious Tecamin Max solution, and dual interaction of plants of the red varities treated with low concentration of the nutritious Tecamin Max solution recorded the highest values in the length and diameter of the root. As for triple interaction regarding the three studied factors results were similar to the singular and dual interaction, where the furrow plants of the red varities which were sprayed with low concentration Tecamin Max resulted in the highest values regarding length and diameter of roots 8.65 and $7.06 \mathrm{~cm}$ consecutively, while plot plants of the red varities of radish that are untreated with the nutritious Tecamin Max solution with the least length being 4.76, while plot black varities plants untreated with nutritious Tecamin Max solution registered the least root diameter of $3.63 \mathrm{~cm}$.

Table (8): Effect of planting method and spraying with Tecamin Max of two varieties of radish on Length of the root $(\mathrm{cm})$.

\begin{tabular}{|c|c|c|c|c|c|c|}
\hline \multirow[t]{2}{*}{ Varieties } & \multirow{2}{*}{$\begin{array}{l}\text { Planting } \\
\text { method }\end{array}$} & \multicolumn{3}{|c|}{ Tecamin Max ml. l $^{-1}$} & \multirow{2}{*}{$\begin{array}{l}\text { Variety X } \\
\text { Planting } \\
\text { method }\end{array}$} & \multirow{2}{*}{$\begin{array}{c}\text { Average of } \\
\text { Planting method }\end{array}$} \\
\hline & & 0 & 3 & 6 & & \\
\hline \multirow{2}{*}{$\begin{array}{l}\text { Red } \\
\text { "Celesta" }\end{array}$} & Plot & $4.76 \mathrm{~d}$ & $6.99 \mathrm{abc}$ & $6.72 \mathrm{bc}$ & $6.16 \mathrm{~b}$ & $6.10 \mathrm{~b}$ \\
\hline & Furrow & $8.13 \mathrm{ab}$ & $8.65 \mathrm{a}$ & $7.09 \mathrm{ab}$ & $8.26 \mathrm{a}$ & $7.26 \mathrm{a}$ \\
\hline \multirow{2}{*}{$\begin{array}{l}\text { Black } \\
\text { "Rudi" }\end{array}$} & Plot & $6.08 \mathrm{~cd}$ & $5.87 \mathrm{~cd}$ & $6.16 \mathrm{~cd}$ & $6.04 \mathrm{~b}$ & \\
\hline & Furrow & $5.84 \mathrm{~cd}$ & $6.95 \mathrm{abc}$ & $5.97 \mathrm{~cd}$ & $6.25 \mathrm{~b}$ & \\
\hline \multirow{2}{*}{$\begin{array}{l}\text { Planting method } \\
\text { X Tecamin Max }\end{array}$} & Plot & $5.42 \mathrm{c}$ & $6.43 \mathrm{bc}$ & $6.44 \mathrm{bc}$ & \multirow{2}{*}{$\begin{array}{c}\text { Average of } \\
\text { Variety }\end{array}$} & \\
\hline & Furrow & $6.98 \mathrm{ab}$ & $7.80 \mathrm{a}$ & $6.98 \mathrm{ab}$ & & \\
\hline \multirow{2}{*}{$\begin{array}{l}\text { Variety X } \\
\text { Tecamin Max }\end{array}$} & Red & $6.44 \mathrm{bc}$ & $7.82 \mathrm{a}$ & $7.35 \mathrm{ab}$ & $6.10 \mathrm{~b}$ & \\
\hline & Black & $5.96 \mathrm{c}$ & $6.41 \mathrm{bc}$ & $6.06 \mathrm{C}$ & $7.26 \mathrm{a}$ & \\
\hline \multicolumn{2}{|c|}{ Average of Tecamin Max } & $6.20 \mathrm{~b}$ & $7.11 \mathrm{a}$ & $6.71 \mathrm{ab}$ & & \\
\hline
\end{tabular}

Average in each column for single and interaction between factores have the same letters are not significant acording to duncan multiple test at $0.05 \%$ 
Table (9): Effect of planting method and spraying with Tecamin Max of two varieties of radish on diameter of the root $(\mathrm{cm})$.

\begin{tabular}{|c|c|c|c|c|c|c|}
\hline \multirow[t]{2}{*}{ Varieties } & \multirow{2}{*}{$\begin{array}{r}\text { Planting } \\
\text { method }\end{array}$} & \multicolumn{3}{|c|}{ Tecamin Max ml. ${ }^{-1}$} & \multirow{2}{*}{$\begin{array}{l}\text { Variety X } \\
\text { Planting } \\
\text { method }\end{array}$} & \multirow{2}{*}{$\begin{array}{c}\text { Average of } \\
\text { Planting method }\end{array}$} \\
\hline & & 0 & 3 & 6 & & \\
\hline \multirow{2}{*}{$\begin{array}{l}\text { Red } \\
\text { "Celesta" }\end{array}$} & Plot & $5.27 \mathrm{abc}$ & $5.95 \mathrm{ab}$ & $5.16 a b c$ & $5.46 \mathrm{~b}$ & $5.08 \mathrm{~b}$ \\
\hline & Furrow & $6.43 \mathrm{ab}$ & $7.06 \mathrm{a}$ & $6.35 \mathrm{ab}$ & $6.60 \mathrm{a}$ & $6.65 \mathrm{a}$ \\
\hline \multirow{2}{*}{$\begin{array}{l}\text { Black } \\
\text { "Rudi" }\end{array}$} & Plot & $3.63 \mathrm{c}$ & $5.68 \mathrm{ab}$ & $4.77 \mathrm{bc}$ & $4.69 \mathrm{~b}$ & \\
\hline & Furrow & $6.35 \mathrm{ab}$ & $6.94 \mathrm{a}$ & $6.78 \mathrm{ab}$ & $6.67 \mathrm{a}$ & \\
\hline \multirow{2}{*}{$\begin{array}{l}\text { Planting method } \\
\text { X Tecamin Max }\end{array}$} & Plot & $4.45 \mathrm{c}$ & $5.81 \mathrm{ab}$ & $4.96 \mathrm{bc}$ & \multirow{2}{*}{$\begin{array}{c}\text { Average of } \\
\text { Variety }\end{array}$} & \\
\hline & Furrow & $6.36 \mathrm{a}$ & $7.00 \mathrm{a}$ & $6.56 \mathrm{a}$ & & \\
\hline \multirow{2}{*}{$\begin{array}{l}\text { Variety X } \\
\text { Tecamin Max }\end{array}$} & Red & $5.85 \mathrm{ab}$ & $6.50 \mathrm{a}$ & $5.76 \mathrm{ab}$ & $6.04 \mathrm{a}$ & \\
\hline & Black & $4.96 \mathrm{~b}$ & $6.31 \mathrm{ab}$ & $5.77 \mathrm{ab}$ & $5.68 \mathrm{a}$ & \\
\hline \multicolumn{2}{|c|}{ Average of Tecamin Max } & $5.41 \mathrm{~b}$ & $6.40 \mathrm{a}$ & $5.76 \mathrm{ab}$ & & \\
\hline
\end{tabular}

Average in each column for single and interaction between factores have the same letters are not significant acording to duncan multiple test at $0.05 \%$

\subsection{Percentage of dry matter in roots (\%)}

Table (10) shows a significant advantage for furrow planting compared to plot planting when it comes to percentage of dry material in roots characteristic with an increase percentage of $5.25 \%$, while no significant differences were noticed in spraying the nutritious solution with either its' concentration levels with the black varieties having a significant advantage over the red varieties regarding this characteristic, with an increase of $24.71 \%$. Dual interaction of studied factors have resulted in the highest recorded values of this characteristic, of $(8.90,10.00$, and 10.03) for furrow planting with low concentration Tecamin Max, furrow planting with the black varieties of radish, and the black varieties of radish with the low concentration of Tecamin Max consecutively. As for triple interaction between furrow planting of the black radish varieties with low concentration nutritious Tecamin Max solution resulting in the highest percentage of dry matter of 10.16, with a significant advantage for the red varieties over all factors. 
Table (10): Effect of planting method and spraying with Tecamin Max of two varieties of radish on dry matter of roots $(\%)$.

\begin{tabular}{|c|c|c|c|c|c|c|}
\hline \multirow[t]{2}{*}{ Varieties } & \multirow{2}{*}{$\begin{array}{r}\text { Planting } \\
\text { Method }\end{array}$} & \multicolumn{3}{|c|}{ Tecamin Max ml.1 ${ }^{-1}$} & \multirow{2}{*}{$\begin{array}{l}\text { Variety X } \\
\text { Planting } \\
\text { method }\end{array}$} & \multirow{2}{*}{$\begin{array}{c}\text { Average of } \\
\text { Planting method }\end{array}$} \\
\hline & & 0 & 3 & 6 & & \\
\hline \multirow{2}{*}{$\begin{array}{l}\text { Red } \\
\text { "Celesta" }\end{array}$} & Plot & $7.07 \mathrm{~b}$ & $6.83 \mathrm{~b}$ & $7.51 \mathrm{~b}$ & $7.14 \mathrm{~b}$ & $8.31 \mathrm{~b}$ \\
\hline & Furrow & $7.59 \mathrm{~b}$ & $7.64 \mathrm{~b}$ & $7.39 \mathrm{~b}$ & $7.54 \mathrm{~b}$ & $8.77 \mathrm{a}$ \\
\hline \multirow{2}{*}{$\begin{array}{l}\text { Black } \\
\text { "Rudi" }\end{array}$} & Plot & $9.07 \mathrm{a}$ & $9.89 \mathrm{a}$ & $9.50 \mathrm{a}$ & $9.49 \mathrm{a}$ & \\
\hline & Furrow & $9.75 \mathrm{a}$ & $10.16 \mathrm{a}$ & $10.10 \mathrm{a}$ & $10.00 \mathrm{a}$ & \\
\hline \multirow{2}{*}{$\begin{array}{l}\text { Planting method } \\
\text { X Tecamin Max }\end{array}$} & Plot & $8.07 \mathrm{a}$ & $8.36 \mathrm{a}$ & $8.51 \mathrm{a}$ & \multirow{2}{*}{$\begin{array}{c}\text { Average of } \\
\text { Variety }\end{array}$} & \\
\hline & Furrow & $8.67 \mathrm{a}$ & $8.90 \mathrm{a}$ & $8.74 \mathrm{a}$ & & \\
\hline \multirow{2}{*}{$\begin{array}{l}\text { Variety X } \\
\text { Tecamin Max }\end{array}$} & Red & $7.33 \mathrm{~b}$ & $7.24 \mathrm{~b}$ & $7.45 \mathrm{~b}$ & $7.34 \mathrm{~b}$ & \\
\hline & Black & $9.41 \mathrm{a}$ & $10.03 \mathrm{a}$ & $9.80 \mathrm{a}$ & $9.75 \mathrm{a}$ & \\
\hline \multicolumn{2}{|c|}{ Average of Tecamin Max } & $8.37 \mathrm{a}$ & $8.63 \mathrm{a}$ & $8.63 \mathrm{a}$ & & \\
\hline
\end{tabular}

Average in each column for single and interaction between factores have the same letters are not significant acording to duncan multiple test at $0.05 \%$

\subsection{The yield plant (g.plant $\left.{ }^{-1}\right)$ and the total yield of roots (t.ha $\left.{ }^{-1}\right)$}

Tables (11 and 12) show a significant increase of furrow planting compared to plot planting when it comes to the characteristic of yield of plant (gm) and the total yield $\left(\mathrm{t} \mathrm{ha}^{-1}\right)$ with an increase of $41.10 \%$ for both characteristic, while we notice the significant advantage of the red varieties over the black varieties with a percentage of $7.64 \%$ for both characteristic spraying with both concentrations used of Tecamin Max has lead to an insignificant increase in the yield plant and the total yield in comparison. As for the affect of the dual interaction of the studied factors, interaction between furrow planting with low concentration of Tecamin Max spray in addition to interaction between furrow planting and the red varieties of planting, and interaction between the red varieties of planting and low concentration of Tecamin Max have resulted in the highest values of the yield plant $(140.4,157.2$, and $124.3 \mathrm{~g}$ ) consecutively, and a total yield of roots $\left(18.72,16.57\right.$, and $\left.20.96 \mathrm{t}^{\mathrm{h} \mathrm{h}^{-1}}\right)$ consecutively. Triple interaction had the furrow planting method of the red varieties with spraying with low concentration Tecamin Max being the highest result of yield plant and the highest total yield of roots of (171.6 $\mathrm{g}$ and $\left.22.88 \mathrm{t}^{-h a^{-1}}\right)$, while the lowest values were with plot planting plants of the same varieties untreated with Tecamin Max, with (46.5 g and 6.24 t.ha ${ }^{-1}$ ) consecutively. 
Table (11): Effect of planting method and spraying with Tecamin Max of two varieties of radish on the yield plant $\left(\right.$ g.plant $\left.{ }^{-1}\right)$.

\begin{tabular}{|c|c|c|c|c|c|c|}
\hline \multirow[t]{2}{*}{ Varieties } & \multirow{2}{*}{$\begin{array}{l}\text { Planting } \\
\text { method }\end{array}$} & \multicolumn{3}{|c|}{ Tecamin Max ml.1 ${ }^{-1}$} & \multirow{2}{*}{$\begin{array}{l}\text { Variety X } \\
\text { Planting } \\
\text { method }\end{array}$} & \multirow{2}{*}{$\begin{array}{l}\text { Average of } \\
\text { Planting } \\
\text { method }\end{array}$} \\
\hline & & 0 & 3 & 6 & & \\
\hline \multirow{2}{*}{$\begin{array}{l}\text { Red } \\
\text { "Celesta" }\end{array}$} & Plot & $46.8 \mathrm{~d}$ & $76.9 \mathrm{~cd}$ & $64.7 \mathrm{~cd}$ & $62.8 \mathrm{c}$ & $78.4 \mathrm{~b}$ \\
\hline & Furrow & $150.7 \mathrm{ab}$ & $171.6 \mathrm{a}$ & $149.2 \mathrm{ab}$ & $157.2 \mathrm{a}$ & $133.1 \mathrm{a}$ \\
\hline \multirow[t]{2}{*}{$\begin{array}{l}\text { Black } \\
\text { "Rudi" }\end{array}$} & Plot & $85.3 \mathrm{bcd}$ & $\begin{array}{c}107.4 \text { a- } \\
\text { d }\end{array}$ & $89.5 \mathrm{bcd}$ & $94.1 \mathrm{bc}$ & \\
\hline & Furrow & $101.5 \mathrm{bcd}$ & $\begin{array}{c}109.2 \text { a- } \\
\mathrm{d}\end{array}$ & $116.5 \mathrm{abc}$ & $109.1 \mathrm{~b}$ & \\
\hline \multirow{2}{*}{$\begin{array}{l}\text { Planting method } \\
\text { X Tecamin Max }\end{array}$} & Plot & $66.0 \mathrm{c}$ & $92.2 \mathrm{bc}$ & $77.1 \mathrm{c}$ & \multirow{2}{*}{$\begin{array}{l}\text { Average of } \\
\text { Variety }\end{array}$} & \\
\hline & Furrow & $126.1 \mathrm{ab}$ & $140.4 \mathrm{a}$ & $132.8 \mathrm{ab}$ & & \\
\hline \multirow{2}{*}{$\begin{array}{l}\text { Variety X } \\
\text { Tecamin Max }\end{array}$} & Red & $98.7 \mathrm{a}$ & $124.3 \mathrm{a}$ & $106.9 \mathrm{a}$ & $110 \mathrm{a}$ & \\
\hline & Black & $93.4 \mathrm{a}$ & $108.3 \mathrm{a}$ & $103.0 \mathrm{a}$ & $101.6 \mathrm{~b}$ & \\
\hline \multicolumn{2}{|c|}{ Average of Tecamin Max } & $96.1 \mathrm{a}$ & $116.3 \mathrm{a}$ & $104.9 \mathrm{a}$ & & \\
\hline
\end{tabular}

Average in each column for single and interaction between factores have the same letters are not significant acording to duncan multiple test at $0.05 \%$

Table (12): Effect of planting method and spraying with Tecamin Max of two varieties of radish on the total yield of roots $\left(\right.$ t.ha $\left.^{-1}\right)$.

\begin{tabular}{|c|c|c|c|c|c|c|}
\hline \multirow[t]{2}{*}{ Varieties } & \multirow{2}{*}{$\begin{array}{l}\text { Planting } \\
\text { method }\end{array}$} & \multicolumn{3}{|c|}{ Tecamin Max ml.1 ${ }^{-1}$} & \multirow{2}{*}{$\begin{array}{l}\text { Variety X } \\
\text { Planting method }\end{array}$} & \multirow{2}{*}{$\begin{array}{l}\text { Average of } \\
\text { Planting } \\
\text { method }\end{array}$} \\
\hline & & 0 & 3 & 6 & & \\
\hline \multirow{2}{*}{$\begin{array}{l}\text { Red } \\
\text { "Celesta" }\end{array}$} & Plot & $6.24 \mathrm{~d}$ & $10.25 \mathrm{~cd}$ & $8.62 \mathrm{~cd}$ & $8.37 \mathrm{c}$ & $10.45 b$ \\
\hline & Furrow & $20.09 \mathrm{ab}$ & $22.88 \mathrm{a}$ & $19.89 \mathrm{ab}$ & $20.96 a$ & $17.74 a$ \\
\hline \multirow{2}{*}{$\begin{array}{l}\text { Black } \\
\text { "Rudi" }\end{array}$} & Plot & $11.37 \mathrm{bcd}$ & $14.32 \mathrm{a}-\mathrm{d}$ & $11.93 \mathrm{bcd}$ & $12.54 \mathrm{bc}$ & \\
\hline & Furrow & $13.53 \mathrm{bcd}$ & $14.56 \mathrm{a}-\mathrm{d}$ & $15.53 \mathrm{abc}$ & $14.54 b$ & \\
\hline \multirow{2}{*}{$\begin{array}{l}\text { Planting method } \\
\text { X Tecamin Max }\end{array}$} & Plot & $8.82 \mathrm{c}$ & $12.29 b c$ & $10.28 \mathrm{c}$ & \multirow{2}{*}{$\begin{array}{c}\text { Average of } \\
\text { Variety }\end{array}$} & \\
\hline & Furrow & $16.81 \mathrm{ab}$ & $18.72 \mathrm{a}$ & $17.7 \mathrm{ab}$ & & \\
\hline \multirow{2}{*}{$\begin{array}{l}\text { Variety X } \\
\text { Tecamin Max }\end{array}$} & Red & $13.16 \mathrm{a}$ & $16.57 \mathrm{a}$ & $14.25 \mathrm{a}$ & $14.66 \mathrm{a}$ & \\
\hline & Black & $12.45 \mathrm{a}$ & $14.44 \mathrm{a}$ & $13.73 a$ & $13.54 \mathrm{~b}$ & \\
\hline \multicolumn{2}{|c|}{ Average of Tecamin Max } & $12.81 \mathrm{a}$ & $15.50 \mathrm{a}$ & $13.98 \mathrm{a}$ & & \\
\hline
\end{tabular}

Average in each column for single and interaction between factores have the same letters are not significant acording to duncan multiple test at $0.05 \%$

\section{DISCUSSION}

Results have shown that furrow planting had a significant advantage when it cames to (number of leaves and leaf area), while the effect was no significant for the rest of the vegetative growth characteristic. The effect was clear for the vegetative growth characteristic in the total yield of roots in length and diameter in the yield plant, and in the total yield, in which furrow planting had the superior over plot planting. This significant increase in the characteristic of the vegetative growth and the total yield of roots is perhaps due to the fact that furrow planting allows 
roots to grow in a better manner through less soil pressure around the stored roots, more ventilation, and allowing water and nutrition's to flow in a better way through the capillary characteristic to the top of the furrow, and not accumulating over plants, all compared to plot planting.

Results of using the nutritious Tecamin Max solution have shown that low concentration of the solution $\left(3 \mathrm{ml} . \mathrm{l}^{-1}\right)$ have provided the highest increase in the (length and diameter of the root), with the increase not significant levels when it comes to most vegetative growth characteristic and the total yield in comparison, and the concentration were not significant difference in vegetative growth characteristic and roots when high concentration of $\left(6 \mathrm{ml} / \mathrm{l}^{-1}\right)$ is used. The positive role which this fertilizer has played is perhaps due to what it contains of aminoacids which reached up to (20) amino-acids (table 2) that were necessary for plant growth, and which stimulate metabolism processes which in turn stimulate growth due to the production of necessary growth proteins, vitamins, and enzymes (Coruzzi and Last, 2000, Attoa et al. 2002), or perhaps the increase is due to amino-acids working on supplying plants with nitro substances needed for growth and vital processes, which include the division and elongation of plant cells (Gamal El-Din et al. 1997).

As for varieties effect, it is noticed that results from both varieties there is no significant difference in most vegetative growth characteristic, and the effect was clear in the characteristic of the outcome, since the red varieties had a higher significant advantage in root length, plant yield, and total yield, while the black varieties had an increase in the percentage of dry matter in roots only. These results are due the nature of growth between the two varieties, to the genetic contrast between different varieties, and to the response of both varieties to the climate environment, which all in consistent with what Esho (2004) has concluded with 5 varieties of radish, and what AbdulRahman (2014) and Hammad (2015) have concluded over two varieties of radish.

\section{تأثير طريقة الزراعة والرش بالمحلول المغذي العضوي Tecamin Max في نمو وحاصل صنفين من الفجل ( RAPHANUS SATIVUS L.)}

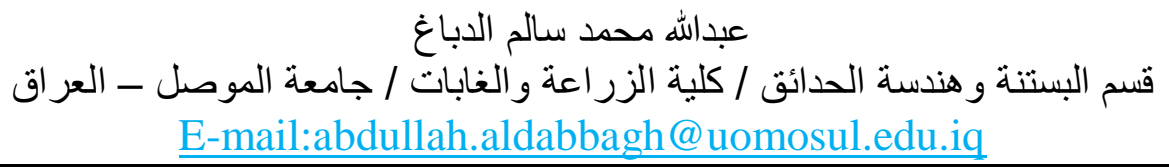

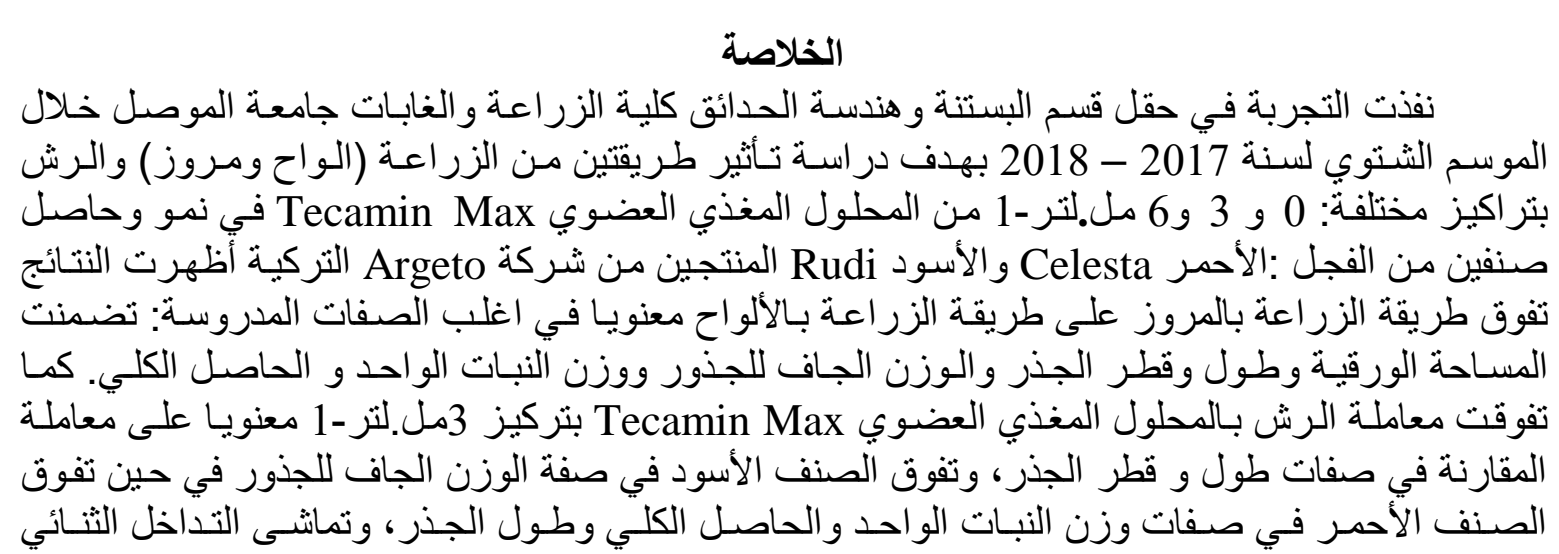




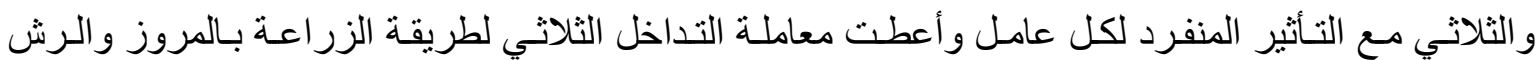

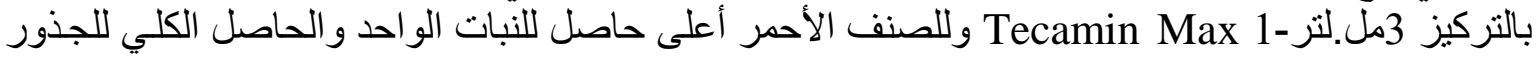

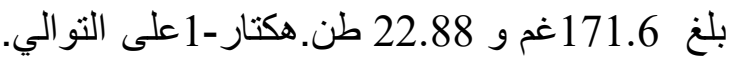

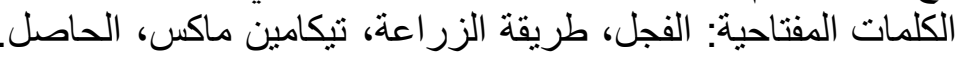
تاريخ استلام البحث: 2019/2/26 ناريخ القبول 2019/6/30

\section{REFERENCES}

Abdel-Gawad, A. A., A. N. Nemat and T. B. Fayed (1989). Introduction to Crop Science (Production Basics). First Edition. The Arab House for Publishing and Distribution / Cairo.

Abdulrhman, H. B. (2014).Effect of spraying Alga600 on the growth and yield of two varieties of the radish Raphanus sativus L. Diyala Journal of Agricultural Sciences.6(1):72.63.

Al-Hamdani, S. A., M. A. Al-Janabi and G. S. Al-Azzawi (2017). The effect of fermentation of foul try fertilizer and spray with Tecamin Max in the growth and yield of potato. (Solanum tuberosum L.). Journal of Agricultural, Environmental and Veterinary Sciences. 4 (1):19-27.

Al-Rawi, K. M. and K. Abdul Aziz. (2000). Design And Analysis Of Agricultural Experiments. University of Al Mosul. Ministry of Higher Education and Scientific Research, Iraq.

Attoa, G. E.; H.E. Wahba and A.A. Farahat (2002). Effect of some amino acids and Sulphur fertilizer on growth and chemical composition of iberis amara L. plant. Egypt. J. Hort.29:17-37.

Boras, M. (1993). Production of Vegetable Crops: Publications of the college of Agriculture, University of Damascus, Syrian Arab Republic, Number of pages: 415.

Cerdana, M.T; A.F. Sanchez- Sanchez;M.D. Oliver; M.T. Juarez and J.J. SanchezAndreu. (2009). Effect of foliar and root applications of amino acide on iron uptake by tomato plants. J. Acta Hort.830:481-488.

Cools, M.H. 1981. Black radish varieties for the spring. Groenten enfruit, 36(26): 34-35.

Coruzzi, G. and R. Last.(2000). Amino Acids. In: Biochemistry and Molecular Biology of Plants. B. Buchanan, w. Gruissem, R. Jones (eds). Amer.Soc. plant Biol.; Rockville, MD, USA.358-410.

Esho, K. B. (2004). Performance and correlations of cegetative growth, yield and its components in five cultivars of radish. Damascus University. Journal of Agricultural Sciences. 20(2): 63-72.

Gamal El-Din, K. M.; S. A. Tarraf and L. K. Balbaa.(1997). Phyiological studies on the effect of some amino acids and microelements on growth and essential oil content in lemon grass (cymbopogon citrates Hort.) J.Agric Sci. Mansoura Univ. 22(12):4229-4241.

Hammad, M. M. (2015). Effect of spraying extracts Humics (ant) on the growth and yield of Radish Raphaus sativus L. Alexandria Journal of Scientific Exchange. 36(2):292-298. 
Hasan. A. A.(2003). Production of Carnivorous and Marmara Vegetables. (Arab House for Publishing and Distribution) Cairo, Egypt.

Hounsome N.W.;B.Y. Hounsome; D.L. Tomos and G.H. Edwards - Jones. (2008). Plant metabolites and nutritional quality of vegetables. J. Food Sci.73 (4):48-65.

Ibrahim, S.K.; M.M. Lobna;S.W. Taha and M.M. Farahat. (2010). Influence of foliar application of pepton on growth, flowering and chemical composition of helichrysum bracteatum plants under different irrigation intervals. Ozean J.Appl.Sci., 3(1):19-29.

Norbut, S. L.(1985). Genetical characters of lines radish. Biologiga. 4: 75-78.

Sadhu, M. K. (1993). Root Crops. In. Boss(ED), Vegetable Crops, Naya prokash, India, pp470-488. 